\title{
Corporate Social Responsibility Applications in Turkish Airport System
}

\author{
Nuriye Güreş ${ }^{1}$, Harun Yılmaz' ${ }^{1}$, Seda Arslan ${ }^{1}$, Cemal Durmuşçelebi ${ }^{1} \&$ Cevher Yüksel ${ }^{2}$ \\ ${ }^{1}$ School of Civil Aviation, Iskenderun Technical University, Hatay, Turkey \\ ${ }^{2}$ School of Foreign Languages, Iskenderun Technical University, Hatay, Turkey \\ Correspondence: Seda Arslan, School of Civil Aviation, Iskenderun Technical University, Iskenderun, 31200 \\ Hatay, Turkey. E-mail: seda.arslan@iste.edu.tr
}

Received: August 3, 2017

doi:10.5539/ijbm.v12n11p52

\author{
Accepted: September 17, 2017 Online Published: October 18, 2017 \\ URL: https://doi.org/10.5539/ijbm.v12n11p52
}

\begin{abstract}
Businesses in aviation industry, where fierce competition has been encountered, have had to pay more attention to their relationships with the environment to increase their market share and to survive. In this context, enterprises have started to focus on corporate social responsibility (CSR) applications to provide sustainability in terms of environmental, social and economic. Although there are many academic studies on this subject in other sectors, it is relatively less in aviation sector. Therefore, in this study, CSR applications in terms of enterprises operating in Turkish airports have been analysed using GRI (Global Reporting Initiatives) scale for the airport system. Within the extent of the research, the necessary information has been obtained through the reports published by the companies, internet pages and social media accounts etc. for CSR activities. Content analysis was used to analyze the data. As a result of the research, it has been determined that the majority of enterprises do not share their CSR applications publicly enough, even if they perform most of these activities. According to the results, suggestions have been made to the airport and terminal operators to apply more effective CSR activities.
\end{abstract}

Keywords: Turkish aviation industry, airport system, corporate social responsibility (CSR)

\section{Introduction}

The term "sustainable aviation" has become commonplace because aviation has a key role in illustrating sustainability as an important source of economic growth and environmental impacts (Kuo et al., 2016). In the aviation industry, where the audience is millions of ordinary people, the value brought by CSR can be particularly important. Therefore, the corporations need to gain a favorable reputation on CSR to have steady customers, competitive advantage over competitors and strengthen their sustainability (Karaman \& Akman, 2017).

The largest environmental impact of aircraft as air pollution, noise pollution and global warming, are often excluded from regulatory attempts at controlling environmental impact, thus, demonstrating a need for CSR in the aviation sector (Durmaz et al., 2011).

The aviation sector affects the world in economic, social and environmental aspects. While the industry creates a world \$ 2.7 trillion economy, it generates approximately 63 million jobs, 10 million of which are direct. The airport system in the aviation sector has also directly and indirectly reached approximately 6 million jobs worldwide (ATAG, 2016).

Airports need to manage CSR strategies for sustainable development (Chang \& Yeh, 2016; Koç \& Durmaz, 2015). In aviation industry, an airport needs to balance its profits and social impacts, by considering the interests of all stakeholders, such as residents, tenants, airlines and travellers (Rawson \& Hooper, 2012). It is important for airports to provide collective useful feedback such as environmental protection, economic value creation and social services in terms of competitive advantage and sustainable development. Thus, in order to meet the expectations of stakeholders, airport operators have begun to focus on CSR implementations. In long term, the airport which has a powerful economic structure, socially meets stakeholders expectations and minimizes negative environmental impacts could be sustainable. In short term companies should provide competitive products and services to sustain economically and also protect the natural and human resources to provide 
continuity for the generation's future needs (Koç \& Durmaz, 2015).

To enhance competitive advantages and ensure sustainable development, airports should take on the mission of society feedback such as environmental protection, economical value creation, and social caring. Hence, it has become a common place for airports to implement CSR activities for meeting their stakeholders' expectations. Publishing CSR reports is a means for airports to communicate and engage with the stakeholders about their CSR activities (Chang \& Yeh, 2016).

Although the fuel efficiency of aircraft has been increased and the emission rate has been reduced depending upon the development of technology, the aviation activities still continue to influence the nature. Today, about $12 \%$ of carbon emissions in the transport sector come from aviation activities (Vinot \& Coussy, 2009). For this reason, aircraft producers, airlines and airports need to balance their environmental impacts in favor of the community. Due to the significant socio-economic and environmental impacts stemming from the nature of operations, airports continue to operate under the sustainable development principles (Jordao, 2009).

There are positive contributions of rapid growth like creating job opportunities, providing fast and secure transportation, rising incomes and the support of other sectors influences social and economic life. Due to the significant socio-economic and environmental impacts inherent to their operations, airports worldwide are increasingly being managed within the framework of sustainable development guiding principles mainly as a response to the pressure received by their various stakeholders (Jordao, 2009; Koç \& Durmaz, 2015). Therefore in this study, CSR activities of enterprises operating in airports have been examined.

\section{Conceptual Background and Research Model}

\subsection{Corporate Social Responsibility}

Over the last two decades the public, governments, customers and other stakeholders have been demonstrating growing awareness of the social and environmental consequences of human activity in general, and business operations in particular. As a result, the idea of sustainability and its three pillars of economic, environmental and social action gained popularity (Grosbis, 2012).

Different stakeholders raise pressures to companies to improve their CSR performances and release the related reports. Such pressures include for example, public concern, regulatory forces, consumer pressure, industry peer pressures, reputation concerns, media interest and perceived market advantage (Chen et al., 2015). Therefore CSR is becoming an essential practice for businesses (Durmaz et al., 2011). From the second half of the 20th century, CSR became increasingly important. Following Bowen's (1953) book, 'Social Responsibilities of the Businessman', the social responsibilities of the business world changed dimension and took place in terminology as CSR.

The importance of CSR has increased till 1960s, with the emerging activities related to human, women, consumer rights and environmental protection (Carroll, 2015). Accordingly, some facts such as society and business, social issues management, public policy and business stakeholder management, and institutional accountability have played a significant role to increase the value of CSR (Matten, et al., 2003).

CSR refers to the fact that the functions of modern enterprises are not merely to make profit and obey the law, but also to have responsibilities towards the community (Carroll, 1991). According to another definition, CSR is the voluntary commitment of a firm to contribute to social and environmental goals (Durmaz et al., 2011). The broader goal of CSR is to create higher standards of living, while preserving the organization' profitability for people inside and outside. In order to reach this, the dialogue with stakeholders becomes crucial (Anholon et al., 2016). Because the strategic integration of CSR implies the communication between a company and its stakeholders (Fernandez-Feijoo et al., 2014).

CSR reporting has positive impacts, including improving corporate reputation, achieving employee trust, enhancing customers' satisfaction, brand value, employees' CSR awareness, communication with stakeholders, management systems, management culture, market share (Kuo et al., 2016; Akmeşe et al., 2016). Also CSR creates values by reducing costs and risks, gaining competitive advantages, developing legitimacy, and searching win-win outcome (Chang \& Yeh, 2016; Durmaz et al., 2011). So businesses should be concerned about the quality of life, in other words, the physical, human and social environment of modern man and modern society (Drucker, 2001: 17). Within the context of CSR, businesses should identify which issues (social, environmental, economic) they need to focus on in their policies, decisions and practices, taking into account the interests of all stakeholders (Brennan \& Solomon, 2008).

The disclosure of information on the exercise of CSR is the mean most frequently used by companies to facilitate understanding of the social and environmental performance of an organisation and to improve 
relationships with stakeholders (Fuente et al., 2017). Because of the positive impacts of CSR on both airport operators and the whole stakeholders, they should apply effective CSR practices and disclose them to the society continuously.

\subsection{Turkish Airport System}

Turkish civil aviation has grown significantly over the world average in recent years. According to the International Air Transport Association (IATA), 40 billion passengers around the world will prefer air transport by the end of 2017 (IATA, 2016a). Again, according to IATA, the growth rate of global air transport by 2035 is $3.7 \%$ annually on average (IATA, 2016b). According to the data provided by the General Directorate of State Airports Authority (DHMI) in December 2016, 174 million passengers were transported by airline companies in Turkey in 2016 (DHMI, 2016). As to another forecast, the Turkish air transport sector will grow at an annual average rate of $4 \%$ until 2021 (Eurocontrol, 2015). Depending on this growth, the number of airports has increased and renewal and expansion works have been done at existing airports.

There are a total of 55 airports open to domestic and international flights in Turkey, and most of the airports are operated by the State Airport Authority (DHMi). In addition, 12 of the 55 airports are operated by government and private partners (DGCA, 2016). Rapid growth experienced by the aviation industry brings some problems such as capacity, demand, investment, operation. Turkey is trying to solve these problems with methods such as build-operate-transfer, rent-operate-transfer. In the long run, the success of these airports will be possible through the establishment of a sustainable economic, environmental and social structure within the framework of CSR.

In the literature, there are various studies related to CSR activities of companies in different industryies such as education, finance, mining, foresty, tourism etc... (Akmeşe et al., 2016; Boiral \& Heras-Saizarbitoria, 2017; Chen et al., 2015; Font et al., 2016; Fuente et al., 2017; Grosbis, 2012; Harvieux et al., 2017). In the literature, there are some studies searching aviation companies' CSR activities (Anholon et al., 2016; Durmaz et al., 2011; Karaman \& Akman, 2017; Kuo et al., 2016; Lynes \& Andrachuk, 2008; Chang \& Yeh, 2016; Koç \& Durmaz, 2015; Oto et al., 2012; Skouloudis et al., 2012; Graham, 2005; Upham \& Mills, 2005; Jordao, 2009; Chang et al., 2015; Wang et al., 2015; Philips, 2006). But especially in our country, there are relatively less studies examining CSR activities of airport operators. Within the scope of this study, research questions are as follows:

1- Do the enterprises operating in Turkish airports provide economic benefits for the internal and external environment within the scope of CSR?

2- Do the enterprises operating in Turkish airports provide environmental benefits for the internal and external environment within the scope of CSR?

3- Do the enterprises operating in Turkish airports provide social benefits for the internal and external environment within the scope of CSR?

\section{Method}

In this study, content analysis, one of the qualitative research methods, has been used to search the activities of the companies operating in Turkish airports within the framework of CSR. Content analysis is a systematic, objective and numerical analysis to measure variables in a text (Bayram \& Yayl1, 2009). In other words, content analysis can be defined as analysing a written, verbal text or symbol into figures and going over the figures to interpret, in other words, to convert the figures back into words (Çiçek et al., 2010).

All of the enterprises under management and operation of the airports in Turkey, 8 enterprises (1 Public, 7 Private) were examined under the research. In this concept, GRI's Sustainability Reporting Standards were used. GRI is an international independent organization that helps businesses, governments and other organizations to understand and communicate the impact of business on critical sustainability issues such as climate change, human rights, corruption and many others. GRI provides the world's most widely used standards on sustainability reporting and disclosure, enabling businesses, governments, civil society and citizens to make better decisions based on information that matters (GRI, 2009). GRI has developed the leading standards or guidelines for CSR reporting (Fernandez-Feijoo et al., 2014) and enhance the credibility of a sustainability report (Harvieux et al., 2017).

In this survey, reports published by companies that are operating in Turkish airports, their internet pages and social media accounts etc. were analysed to reveal their CSR activities. The enterprises covered by the survey were examined and compared in terms of economic, social and environmental indicators. 


\section{Results}

\subsection{The Economic Activities of the Enterprises Operating in Turkish Airports within the scope of CSR}

The economic activities of companies operating in Turkish airports within the scope of CSR were examined through the reports published by the companies, their internet pages and social media accounts etc. The findings were shown in Table 1.

Table 1. Economic indicators

\begin{tabular}{|c|c|c|c|c|c|c|c|}
\hline & & \multicolumn{2}{|c|}{ YES } & \multicolumn{2}{|c|}{$\mathrm{NO}$} & \multicolumn{2}{|c|}{ TOTAL } \\
\hline & & $\mathrm{N}$ & $\%$ & $\mathrm{~N}$ & $\%$ & $\mathrm{~N}$ & $\%$ \\
\hline $\begin{array}{l}\text { Economic } \\
\text { performance }\end{array}$ & Financial indicators & 5 & 63,00 & 3 & 37,00 & 8 & 100,00 \\
\hline \multirow{2}{*}{$\begin{array}{l}\text { Presence in the } \\
\text { market }\end{array}$} & $\begin{array}{l}\text { Number of passengers per year } \\
\text { (Domestic / international / passenger / } \\
\text { transit passenger) }\end{array}$ & 5 & 63,00 & 3 & 37,00 & 8 & 100,00 \\
\hline & $\begin{array}{l}\text { Annual number of aircraft (such as } \\
\text { general aviation / commercial } \\
\text { passenger and cargo transport / } \\
\text { official flights) }\end{array}$ & 4 & 50,00 & 4 & 50,00 & 8 & 100,00 \\
\hline \multirow{2}{*}{$\begin{array}{l}\text { Indirect economic } \\
\text { effects }\end{array}$} & $\begin{array}{l}\text { Contributing to the development of } \\
\text { other sectors in the region in } \\
\text { operation }\end{array}$ & 5 & 63,00 & 3 & 37,00 & 8 & 100,00 \\
\hline & $\begin{array}{l}\text { Development of infrastructure } \\
\text { investment and services }\end{array}$ & 6 & 75,00 & 2 & 25,00 & 8 & 100,00 \\
\hline $\begin{array}{l}\text { Purchase } \\
\text { applications }\end{array}$ & Supply chain applications & 4 & 50,00 & 4 & 50,00 & 8 & 100,00 \\
\hline
\end{tabular}

As shown in Table 1, most of the companies operating in Turkish airports have published their financial indicators. As their presence in the market; $63 \%$ of the companies stated the number of passengers per year and half of them specified annual aircraft traffic. When the indirect economic effects of the companies were considered, it has been seen that 5 out of 8 operators publish information about contributing to the development of other sectors in the region. Also the vast majority of them inform about the development of infrastructure investments and services. For purchasing applications, only half of the companies' information could be reached.

\subsection{Environmental Activities of the Enterprises Operating in Turkish Airports within the Scope of the CSR}

As shown in Table 2, when the environmental activities carried out by the enterprises operating in Turkish airports are examined within CSR, it has been observed that the vast majority of businesses have implemented energy management systems. In addition, most of them have energy and environmental certifications, focused and published on energy saving practices. It has been determined that half of the enterprises are committed to efficient use of natural water resources. Similarly they reduce pollutants and chemicals entering clean water sources and share them with internal and external stakeholders. Also only 2 of the enterprises informed about minimizing the negative impact of their aviation operations at the airports on the natural environment.

Furtermore, It has been determined that $75 \%$ of the enterprises own airport carbon accreditation within the scope of their emission applications. Same number of enterprises have taken emission reduction measures derived from aviation operations, carried out activities to reduce greenhouse gas emissions and given information about them in their reports. Within the scope of wastewater and wastes; it has been seen that 5 companies have issued waste management practices and published a responsibility report on the importance of recycling and the transport of wastes. In addition, it has been determined that half of the enterprises have noise management applications. They have set noise targets or limits at airports and announced it with different media tools. 
Table 2. Environmental indicators

\begin{tabular}{|c|c|c|c|c|c|c|c|}
\hline & & \multicolumn{2}{|c|}{ YES } & \multicolumn{2}{|c|}{ NO } & \multicolumn{2}{|c|}{ TOTAL } \\
\hline & & $\mathrm{N}$ & $\%$ & $\mathrm{~N}$ & $\%$ & $\mathrm{~N}$ & $\%$ \\
\hline \multirow{3}{*}{ Energy } & Energy management system & 6 & 75,00 & 2 & 25,00 & 8 & 100,00 \\
\hline & $\begin{array}{l}\text { Energy and environmental } \\
\text { certifications }\end{array}$ & 6 & 75,00 & 2 & 25,00 & 8 & 100,00 \\
\hline & $\begin{array}{l}\text { Energy saving practices as } \\
\text { airport operators }\end{array}$ & 6 & 75,00 & 2 & 25,00 & 8 & 100,00 \\
\hline \multirow[t]{2}{*}{ Water } & $\begin{array}{l}\text { Reduction of pollutants and } \\
\text { chemicals entering clean } \\
\text { water sources }\end{array}$ & 4 & 50,00 & 4 & 50,00 & 8 & 100,00 \\
\hline & $\begin{array}{l}\text { Efficient use of natural water } \\
\text { resources }\end{array}$ & 4 & 50,00 & 4 & 50,00 & 8 & 100,00 \\
\hline Biodiversity & $\begin{array}{l}\text { Reducing the negative effects } \\
\text { of aeronautical operations at } \\
\text { airports on the natural } \\
\text { environment }\end{array}$ & 2 & 25,00 & 6 & 75,00 & 8 & 100,00 \\
\hline \multirow{3}{*}{ Emission } & Airport carbon accreditation & 6 & 75,00 & 2 & 25,00 & 8 & 100,00 \\
\hline & $\begin{array}{l}\text { Aviation operations derived } \\
\text { emission reduction measures }\end{array}$ & 6 & 75,00 & 2 & 25,00 & 8 & 100,00 \\
\hline & $\begin{array}{l}\text { Reduction of greenhouse gas } \\
\text { emissions }\end{array}$ & 6 & 75,00 & 2 & 25,00 & 8 & 100,00 \\
\hline \multirow{2}{*}{$\begin{array}{l}\text { Waste Water and } \\
\text { Wastes }\end{array}$} & $\begin{array}{l}\text { Waste management practices } \\
\text { and recycling }\end{array}$ & 5 & 63,00 & 3 & 37,00 & 8 & 100,00 \\
\hline & $\begin{array}{l}\text { Liability report on the } \\
\text { transport of wastes }\end{array}$ & 5 & 63,00 & 3 & 37,00 & 8 & 100,00 \\
\hline \multirow{2}{*}{ Noise } & $\begin{array}{l}\text { Noise } \\
\text { applications }\end{array}$ & 4 & 50,00 & 4 & 50,00 & 8 & 100,00 \\
\hline & $\begin{array}{l}\text { Determination of noise targets } \\
\text { or limits at airports }\end{array}$ & 4 & 50,00 & 4 & 50,00 & 8 & 100,00 \\
\hline
\end{tabular}

\subsection{Social Activities of the Enterprises Operating in Turkish Airports within the Scope of the CSR}

When the social indicators were examined, it has been seen that very few of the businesses have provided information about their activities on the fight against corruption and local people' rights. The vast majority of enterprises involved in this research are engaged in employment practices and decent works (employment, occupational health and safety, education, diversity and equal opportunities) and have announced these activities to the stakeholders (Table 3).

The majority of businesses have not shared information about the activities they do related to human rights (prevention of discrimination, child labour) practices. Finally, $75 \%$ of businesses have a number of activities on product liability (customer satisfaction, quality of products and services, barrier-free airport) and publish them in sustainability reports.

Table 3. Social indicators

\begin{tabular}{|c|c|c|c|c|c|c|c|}
\hline & & \multicolumn{2}{|c|}{ YES } & \multicolumn{2}{|c|}{ NO } & \multicolumn{2}{|c|}{ TOTAL } \\
\hline & & $\mathrm{N}$ & $\%$ & $\mathrm{~N}$ & $\%$ & $\mathrm{~N}$ & $\%$ \\
\hline \multirow{2}{*}{ Society } & Fight against corruption & 2 & 25,00 & 6 & 75,00 & 8 & 100,00 \\
\hline & Rights of indigenous peoples & 3 & 37,00 & 5 & 63,00 & 8 & 100,00 \\
\hline \multirow{4}{*}{$\begin{array}{l}\text { Employment Practices } \\
\text { and decent work }\end{array}$} & Employment & 6 & 75,00 & 2 & 25,00 & 8 & 100,00 \\
\hline & Occupational health and safety & 6 & 75,00 & 2 & 25,00 & 8 & 100,00 \\
\hline & Education & 6 & 75,00 & 2 & 25,00 & 8 & 100,00 \\
\hline & Diversity and equal opportunity & 6 & 75,00 & 2 & 25,00 & 8 & 100,00 \\
\hline
\end{tabular}




\begin{tabular}{llllllll}
\hline \multirow{3}{*}{ Human rights } & Prevention of discrimination & 2 & 25,00 & 6 & 75,00 & 8 & 100,00 \\
& Child Labour & 2 & 25,00 & 6 & 75,00 & 8 & 100,00 \\
\multirow{3}{*}{ Product liability } & Customer Satisfaction & 6 & 75,00 & 2 & 25,00 & 8 & 100,00 \\
& Quality of products and services & 6 & 75,00 & 2 & 25,00 & 8 & 100,00 \\
& Airport for the disabled & 6 & 75,00 & 2 & 25,00 & 8 & 100,00 \\
\hline
\end{tabular}

\section{Discussion and Conclusion}

In this study, the economic, environmental and social benefits provided by the enterprises operating in Turkish airports to the internal and external environment within the scope of CSR and their state of informing the public about these issues were investigated. As a result of the research, it has been determined that the majority of enterprises do not share them publicly enough, even if they perform these activities within the scope of CSR. Similarly, Skouloudis et al. (2012) indicated that CSR reporting was not a common practice among international airport. However, it is important that all actors in the aviation sector should use all media channels with CSR consciousness; publish their activities in a transparent, accessible and plain language to ensure competitive advantage and be sustainable in the sector. Airport operators should share more information on their economic performance and their presence in the market (number of passengers per year, annual aircraft traffic, etc.). Thus, they will be able to become more transparent and accountable to internal and external stakeholders.

In addition to the aviation sector in which they operate, the operators provide economic contribution indirectly to tourism and many other sectors. These businesses provide direct employment opportunities, also support sub-sectors they cooperate with. Thus the economy might be stimulated in general and this creates a multiplier effect. Especially by utilizing the local supply chain and distribution channels, more benefits can be provided. Therefore, creating value for customers by cooperating with these businesses in the marketing chain is of utmost importance in terms of sustainability. It is important that the companies which the aviation companies will cooperate with should have some qualifications to establish a successful system. They should have high operational abilities, be professional, take solution-oriented approaches to problems, consider environmental and social criterias.

The airport operators should continuously develop and present improved, fast and safe infrastructure facilities by utilizing new technologies for airlines, ground handling operators and other stakeholders. Also, they should carry out social investment programs in addition to their main activities such as social projects (health, unhindered life, education, culture-arts, sports, animal protection etc.). Thus, the region in which the activity is carried out will be benefited both socially and economically.

It is crucial that airport operators should implement the energy and environmental management systems within the scope of CSR. Thus they might save energy, minimize the environmental impact resulting from the activities carried out and create an environment friendly airport. In addition, encouraging eco-friendly and energy-saving approaches to be used by supply chain and distribution channel members may also help raise awareness and reduce negative environmental impacts.

Airport operators should provide conservation of biodiversity and minimize losses in natural habitats and keep the lowest level of carbon emissions within environmental management. They should also include these in business processes sustainably.

Furthermore, airport operators should use natural water resources efficiently, reduce pollutants and chemicals entering clean water sources. Also they should reduce the amount of water consumed per passenger and the harm to nature by recycling waste water. In addition, waste management policies including the recycling and destruction of other wastes such as paper, plastic, glass should be implemented. An another factor that must be taken into consideration by the operators to manage the noise effectively in accordance with both national and international standards. It is also a requirement of CSR that operators should be aware of their responsibilities towards community and provide social benefits during their activities. In order to contribute to the social welfare of the society, they should do some activities in different areas such as health, education, culture-arts, sports, animals and nature conservation. It is also important to avoid and prevent illegal practices as corruption, bribery, smuggling (human, animal, drug, historical monuments, etc.) that might occur in airport operations.

Moreover, airport businesses should provide employment opportunities to disadvantaged segments (women, young people, disabled and educated unemployed) to improve the economic and social life of the region. Establishing a safe and peaceful work environment where participatory management is dominant is of utmost 
importance in terms of employee satisfaction. Thus lifelong learning culture might be adopted (such as continuous development for leaders, e-learning and distance learning, rich professional and personal development opportunities) and all employees can develop themselves continuously. Employee well-being and engagement receives the highest grade (Cowper-Smith \& Grosbois, 2011; Wang et al., 2015; Chang et al., 2015; Karaman \& Akman, 2017). In addition to this, it is becoming a necessity for the operators to apply a human resource policy respecting multicultural and cultural differences. So they might present equal opportunities to all employees without distinction of language, religion, race and sex.

It is also one of the important indicators of CSR that airport operators should provide passengers fast, comfortable, safe and high-quality travel experience. In order to establish long-term relationships with airlines which are their another customers, they should meet their needs too. The impacts of the products and services, which increase customer satisfaction, are viewed as the most important factor in CSR formation and customer focus and service quality are the most important dimensions of CSR implementation (Wang et al., 2015; Chang \& Yeh, 2016; Karaman \& Akman, 2017). Accordingly, it is necessary for airport operators to provide high quality services to their customers by utilizing new technologies (mobile applications etc.). For whole passengers, especially disabled, having equal service conditions within the airport is a crucial factor in terms of customer satisfaction and CSR.

As a limitation of this study, most of the enterprises operating in Turkish airports do not publish or share their CSR applications in terms of environmental, social and economic. Therefore it was hard to reach the necessary data about this topic. As the further research, CSR applications of airlines may be examined and the comparisons may be made among the enterprises operating in airports and airlines in different countries.

\section{References}

Air Transport Action Group (ATAG). (2016). Aviation: Benefits beyond borders. Retrieved from http://www.atag.org/our-publications/latest.html/

Akmeşe, H., Çetin, B., \& Akmeşe, K. (2016). Corporate social responsibility reporting: a comparative analysis of tourism and finance sectors of G8 countries. Procedia Economics and Finance, 39, 737-745. https://doi.org/10.1016/S2212-5671(16)30273-8

Anholon, R., Quelhas, O. L. G., Filho, W. L., Pinto, J. S., \& Feher, A. (2016). Assessing corporate social responsibility concepts used by a Brazilian manufacturer of airplanes: A case study at Embraer. Journal of Cleaner Production, 135, 740-749. http://dx.doi.org/10.1016/j.jclepro.2016.06.169

Bayram, M., \& Yaylı, A. (2009). Otel web sitelerinin içerik analizi yöntemiyle değerlendirilmesi. Elektronik Sosyal Bilimler Dergisi, 8(27), 347-379.

Boiral, O., \& Heras-Saizarbitoria, I. (2017). Corporate commitment to biodiversity in mining and forestry: Identifying drivers from GRI reports. Journal of Cleaner Production, 162, 153-161. http://dx.doi.org/10.1016/j.jclepro.2017.06.037

Bowen, H. R. (1953). Social responsibility of the businessman. New York: Harper \& Row.

Brennan, N. M., \& Solomon, J. (2008). Corporate governance, accountability and mechanisms of accountability: an overview. Accounting, Auditing \& Accountability Journal. 21(7), 885-906. https://doi.org/10.1108/09513570810907401

Carroll, A. B. (1991). The pyramid of corporate social responsibility: Towards the moral management of $\begin{array}{lllll}\text { organizational stake } & \text { holders. } & \text { 34-48iness }\end{array}$ https://doi.org/10.1016/0007-6813(91)90005-G

Carroll, A. B. (2015). Corporate social responsibility: The center piece of competing and complementary frameworks. Organizational Dynamics, 44(2), 87-96. https://doi.org/10.1016/j.orgdyn.2015.02.002

Chang, D. S., Chen, S. H., Hsu, C. W., \& Hu, A. H. (2015). Identifying strategic factors of the implantation CSR in the airline industry: The case of Asia-Pacific airlines. Sustainability, 7(6), 7762-7783. http://dx.doi.org/10.3390/su7067762

Chang, Y. H., \& Yeh, C. H. (2016). Managing corporate social responsibility strategies of airports: The case of Taiwan's Taoyuan International Airport Corporation. Transportation Research Part A, 92, 338-348. http://dx.doi.org/10.1016/j.tra.2016.06.015

Chen, L., Feldmann, A., \& Tang, O. (2015). The relationship between disclosures of corporate social performance and financial performance: Evidences from GRI reports in manufacturing industry. 
International Journal of Production Economics, 170, 445-456.

Çiçek, H., Demirel, M., \& Onat, O. K. (2010). İşletmelerin web sitelerinin değerlendirilmesine ilişkin bir araştırma: Burdur ili örneği. Süleyman Demirel Üniversitesi İktisadi ve İdari Bilimler Fakültesi Dergisi, 15(2), 187-206.

Cowper-Smith, A., \& Grosbois, D. D. (2011). The adoption of corporate social responsibility practices in the $\begin{array}{lllll}\text { airline industry. Journal of } & \text { Sustainable }\end{array}$ http://dx.doi.org/10.1080/09669582.2010.498918

Devlet Hava Meydanları İşletmesi Genel Müdürlüğü (DHMI). (2016). 2016 Yllı aralık sonu yolcu trafiği istatistiği. http://www.dhmi.gov.tr/istatistik.aspx

Directorate General of Civil Aviation (DGCA) (2016). Annual report. Retrieved from http://web.shgm.gov.tr/documents/sivilhavacilik/files/pdf/kurumsal/raporlar/2015_faaliyet_raporu_29.02.20 16.pdf/

Drucker, P. F. (2001). The essential Drucker: The best sixty years of Peter Drucker's essential writings on management. Harper: New York.

Durmaz, A., Ateş, S.S. \& Duman, G. (2011). CSR as a tool to cope with economic crises: The case of TEI. Procedia Social and Behavioral Sciences, 24, 1418-1426. http://dx.doi.org/10.1016/j.sbspro.2011.09.098

Eurocontrol (2015). Seven-year forecast: Flight movements and service units 2015 - 2021. Retrieved from https://www.eurocontrol.int/sites/default/files/content/documents/official-documents/forecasts/seven-year-fl ights-service-units-forecast-2015-2021-Feb2015.pdf

Fernandez-Feijoo, B., Romero, S., \& Ruiz, S. (2014). Commitment to corporate social responsibility measured through global reporting initiative reporting: Factors affecting the behavior of companies. Journal of Cleaner Production, 81, 244-254. http://dx.doi.org/10.1016/j.jclepro.2014.06.034

Font, X., Guix, M., \& Bonilla-Priego, M. J. (2016). Corporate social responsibility in cruising: Using materiality analysis to create shared value. Tourism Management, 53, 175-186. http://dx.doi.org/10.1016/j.tourman.2015.10.007

Fuente, J. A., García-Sánchez, I. M., \& Lozano, M. B. (2017). The role of the board of directors in the adoption of GRI guidelines forthe disclosure of CSR information. Journal of Cleaner Production, 141, 737-750. http://dx.doi.org/10.1016/j.jclepro.2016.09.155

Global Reporting Initiative. (2009). A snapshot of sustainability reporting in the airports sector. 1001 EA Amsterdam The Netherlands. Retrieved from https://www.globalreporting.org/resourcelibrary/A-Snapshot-of-sustainability-reporting-in-the-Airports-Sec tor.pdf

Graham, A. (2005). Airport benchmarking: A review of the current situation. Benchmarking: An International Journal, 12(2), 99-111. https://doi.org/10.1108/14635770510593059

Grosbois, D.D. (2012). Corporate social responsibility reporting by the global hotel industry: Commitment, initiatives and performance. International Journal of Hospitality Management, 31, 896-905. https://doi.org/10.1016/j.ijhm.2011.10.008

Hervieux, C., McKee, M., \& Driscoll, C. (2017). Room for improvement: Using GRI principles to explore potential for advancing PRME SIP reporting. The International Journal of Management Education, 15, 219-237. http://dx.doi.org/10.1016/j.ijme.2017.03.011

http://dx.doi.org/10.1016/j.ijpe.2015.04.004

International Air Transport Association (IATA). (2016a). Another strong year for airline profits in 2017. Retrieved from http://www.iata.org/pressroom/pr/Pages/2016-12-08-01.aspx

International Air Transport Association (IATA). (2016b). IATA forecasts passenger demand to double over 20 years. Retrieved from http://www.iata.org/pressroom/pr/Pages/2016-10-18-02.aspx

Jordao, C. (2009). A sustainability overview of the best practices in the airport sector. Scientific papers of the University of Pardubice, Series D, Faculty of Economics and Administration, (15). http://dspace.upce.cz/handle/10195/35681/

Karaman, A. S., \& Akman, E. (2017). Taking-off corporate social responsibility programs: An AHP application in airline industry. Journal of Air Transport Management (2017). 
http://dx.doi.org/10.1016/j.jairtraman.2017.06.012

Koç, S., \& Durmaz, V. (2015). Airport corporate sustainability: An analysis of indicators reported in the sustainability practices. Procedia - Social and Behavioral Sciences, 181, 158-170. http://dx.doi.org/10.1016/j.sbspro.2015.04.877

Kuo, T. C., Okudan Kremer, G. E., Phuong, N. T., \& Hsu, C. W. (2016). Motivations and barriers for corporate social responsibility reporting: Evidence from the airline industry. Journal of Air Transport Management, 57, 184-195. http://dx.doi.org/10.1016/j.jairtraman.2016.08.003

Lynes, J. K., \& Andrachuk, M. (2008). Motivations for corporate social and environmental responsibility: A case study of Scandinavian Airlines. Journal of International Management, 14, 377-390. http://dx.doi.org/10.1016/j.intman.2007.09.004

Matten, D., Crane, A., \& Chapple, W. (2003). Behind the mask: Revealing the true face of corporate citizenship. Journal of Business Ethics, 45(1-2), 109-120. https://doi.org/10.1023/A:1024128730308

Oto, N., Cobanoglu, N., \& Geray, C. (2012). Education for sustainable airports. Procedia - Social and Behavioral Sciences, 47, 1164-1173. https://doi.org/10.1016/j.sbspro.2012.06.795

Philips, E. D. (2006). Corporate social responsibility in aviation. Journal of Air Transportation, 11 (1), 65-87.

Rawson, R., \& Hooper, P.D. (2012). The importance of stake holder participation to sustainable airport master planning in the UK. Environmental Development, 2, 36-47. https://doi.org/10.1016/j.envdev.2012.03.013

Skouloudis, A., Evangelinos, K., \& Moraitis, S. (2012). Accountability and stakeholder engagement in the airport industry: An assessment of airports' CSR reports. Journal of Air Transport Management, 18, 16-20. https://doi.org/10.1016/j.jairtraman.2011.06.001

Upham, P. J., \& Mills, J. N. (2005). Environmental and operational sustainability of airports: Core indicators and stakeholder communication. Benchmarking: An International Journal, 12(2), 166-179. https://doi.org/10.1108/14635770510593103

Vinot, S., \& Coussy, P. (2009). Greenhouse gas emissions and the transport sector. IFP: Panorama. http://www.ifpenergiesnouvelles.com/Publications/Available-studies/Panorama-technical-reports/Panorama $-2009 /$

Wang, Q., Wu, C., \& Sun, Y. (2015). Evaluating corporate social responsibility of airlines using entropy weight and grey relation analysis. Journal of Air Transport Management, 42, 55-62. https://doi.org/10.1016/j.jairtraman.2014.08.003

\section{Copyrights}

Copyright for this article is retained by the author(s), with first publication rights granted to the journal.

This is an open-access article distributed under the terms and conditions of the Creative Commons Attribution license (http://creativecommons.org/licenses/by/4.0/). 